\title{
FAKTOR-FAKTOR KESULITAN BELAJAR FISIKA PADA PESERTA DIDIK KELAS IPA SEKOLAH MENENGAH ATAS
}

\author{
Abbas, Muhammad Yusuf Hidayat \\ Pendidikan Fisika Fakultas Tarbiyah dan Keguruan UIN Alauddin Makassar, abbasputrarahman95@gmail.com
}

\begin{abstract}
Pada umunya kesulitan merupakan suatu kondisi tertentu yang ditandai dengan adanya hambatan-hambatan dalam kegatan mencapai tujuan, sehingga memerlukan kegiatan yang lebih giat lagi untuk dapat mengatasi. Kesulitan belajar dapat diartikan sebagai kondisi dalam proses belajar yang ditandai adanya hambatan-hambatan tertentu untuk mencapai hasil belajar. Hambatan ini mungkin disadari dan mungkin dapat tidak disadari dan dapat bersifat sosiologis, psikologis atau pun psiologis dalam keseluruhan proses belajarnya. Penelitian ini merupakan penelitian kualitatif yang bersifat deskriptif, karena dalam penelitian ini berusaha menggambarkan suatu obyek tertentu yang dijadikan penelitian. Penelitian yang bertujuan untuk memperoleh informasi tentang faktor-faktor kesulitan belajar fisika pada peserta didik dan upaya guru dalam mengatasi kesulitan belajar fisika pada peserta didik. Penelitian ini menggunakan tiga tehnik pengumpulan data diantaranya observasi, dokumentasi dan wawancara. Sampel sumber data dalam penelitian ini adalah seluruh peserta didik kelas IPA yang mengalami kesulitan belajar. Data yang diperoleh dianalisis selama dan setelah penelitian dengan tiga tahapan yaitu reduksi data, display data dan verifikasi/menyimpulkan. Dari hasil penelitian, faktor internal meliputi kesehatan yang sering terganggu, kurangnya minat belajar, kurangnya perhatian dalam pembelajaran, malas belajar dan kebiasaan belajar yang tidak teratur. Faktor ekternal meliputi pembelajaran yang diselenggarakan dimana peserta didik dalam jumlah besar (padat), kurangnya tontrol orang tua, tuntutan pekerjaan, aktif berorganisasi, teman sepermainan yang nakal dan pergaulan bebas. Sedangkan, Upaya guru dalam mengatasi kesulitan belajar fisika pada dasarnya bervariasi sesuai karakter masing-masing. Dari Upaya guru di Sekolah Menengah Atas meliputi melakukan pengajaran remedial, pengayaan, motivasi, menggunakan berbagai metode pembelajaran, melengkapi kekurangan peralatan belajar, pengembangan kebiasaan yang baik, bimbingan konseling dan melakukan kerja sama antara pihak sekolah dan masyarakat. Implikasi dalam penelitian ini adalah sebaiknya faktor-faktor kesulitan belajar mata pelajaran fisika pada peserta didik dapat dikenali oleh setiap guru fisika agar dapat segera melakukan berbagai pendekatan dalam upaya menanggulangi kesulitan tersebut.
\end{abstract}

Kata kunci: "Faktor, kesulitan, belajar, dan pendidikan".

\section{Pendahuluan}

Penyelenggaraan pendidikan disekolah yang melibatkan guru sebagai pendidik dan siswa sebagai peserta didik, diwujudkan dengan adanya interaksi belajar mengajar atau proses pembelajaran. Dengan konteks pembelajaran ini, guru dengan sadar merencanakan kegiatan pengajaran secara sistematis dan berpedoman pada seperangkat atauran dan rancana tentang pendidikan yang dikemas dalam kurikulum. Pendidikan berarti bimbingan yang diberikan seseorang terhadap perkembangan orang lain menuju kearah cita-cita tertentu yang menentukan manusia untuk berbuatan mengisi kehidupan untuk mencapai keselamatan dan kebahagiaan.
Tujuan pendidikan nasional berfungsi memberikan arah kepada semua kagiatan pendidikan dalam satuan-satuan pendidikan yang ada. Tujuan pendidikan nasional tersebut merupakan tujuan umum yang hendak dicapai oleh semua satuan pendidikannya. Meskipun setiap satuan pendidikan tersebut mempunyai tujuan sendiri, namun tidak terlepas dari tujuan pendidikan nasional. Dalam sistem pendidikan nasional, peserta didiknya adalah semua warga negara. Artinya, semua satuan pendidikan yang ada harus memberikan kesempatan menjadi peserta didiknya kepada semua warga negara yang memenuhi persyaratan tertentu sesuai dengan kekhususannya, tanpa membedakan status sosial, ekonomi, agama, suku bangsa dan sebagainya. 
Agar tercapai tujuan dalam proses belajar mengajar, siswa sebagai faktor utama yang wajib dipahami sebelumnya dengan jelas, baik rohani maupun jasmaninya. Dalam proses belajar mengajar siswa dapat berperan sebagai objek atau subjek. Dikatakan sebagai objek, karena menjadi sasaran dalam proses mengajar guru. Dikatakan subyek karena siswa merupakan pelaku dalam proses pembelajaran yang didalamnya akan membiasakan diri belajar agar terjadi perubahan pada dirinya baik dalam ranah kognitif, avektif, dan psikomotorik.

Selama ini hambatan yang dialami siswa selama melaksanakan kegiatan belajarnya. Yang dikejar hanyalah terpenuhinya target KKM dan hasil belajar maksimal yang paksaan, misalnya sistem belajar drill, tanpa mau tahu bahwa ada sebagian siswa yang merasa kesulitan dalam belajarnya. Pada umunya kesulitan merupakan suatu kondisi tertentu yang ditandai dengan adanya hambatanhambatan dalam kegatan mencapai tujuan, sehingga memerlukan kegiatan yang lebih giat lagi untuk dapat mengatasi.

Menurut Trianto dalam bukunya, menyebutkan bahwa fisika merupakan salah satu cabang dari IPA dan merupakan ilmu yang lahir dan berkembang lewat langkah-langkah ilmiah, mulai dari perumusan masalah, penyusunan hipotesis, pengujian hipotesis melalui eksperimen, penarikan kesimpulan, serta penemuan teori dan konsep. Mempelajari fisika merupakan suatu petualangan. Anda akan menemukan bahwa ilmu ini begitu menantang, kadang-kadang membuat frustasi, sewaktu-waktu menyakitkan, dan seringkali bermanfaat dan memberikan kepuasan batin. Fisika akan menarik rasa estetis seperti halnya intelektualitas anda.

Kesulitan belajar dapat diartikan sebagai kondisi dalam proses belajar yang ditandai adanya hambatan-hambatan tertentu untuk mencapai hasil belajar. Hambatan ini mungkin disadari dan mungkin dapat tidak disadari dan dapat bersifat sosiologis, psikologis atau pun psiologis dalam keseluruhan proses belajarnya. Orang yang mengalami hambatan dalam proses mencapai hasil belajarnya akan mendapat hasil dibawah yang semestinya. Hal ini sesuai dengan pendapat Allan O.Rpss: "A learning difficulty represent a dicrepency beetwen a child's estimated and his actual level of academeic performance
Menurut (Abdurrahman, 2003), ada beberapa faktor kesulitan belajar yang dapat mempengaruhi siswa diantaranya faktor internal siswa: kadaan yang muncul dari dalam diri sendiri atau kekurangmampuan psiko-fisik siswa yaitu (1) Bersifat kognitif (secara sederhana dapat dipahami bahwa hal ini mencakuppsikologis proses psikologis, yang mana setiap anak berbeda dalam kemampuan mental yang mendasari mereka memproses da menggunakan informasi, dan perbedaan tersebut mempengaruhi proses belajar anak) (2) Bersifat afektif (Ranah rasa)= labilnya emosi dan sikap (3) Bersifat psikomotor (Ranah karsa) = terganggunya alat-alat indra penglihatan dan pendengaran.

Semntara faktor ekternal meliputi: (1) Lingkungan Keluarga seperti broken home, rendah kehidupan ekonomi. Pengaruh keluarga yang tidak harmonis yang mempengaruhi perkembangan mental seseorang. Apalagi jika berada dalam lingkungan keluarga yang memiliki kehidupan ekonomi yang pas-pasan atau bahkan berkekurangan. Hal ini dapat berdampak bagi melemahnya kemampuan seseorang dalam menyerap materi pelajaran yang semestinya dikuasai, (2) Lingkungan Masyarakat seperti perkampungan kumuh, teman sepermainan yang nakal. Lingkungan rumah yang terletak di area yang kumuh, jauh dari ketenangan dan ketentraman tentu akan memberi dampak bagi perkembangan, mental seseorang. Biasanya pengaruh yang ditimbulkan adalah bersifat negatif, perokok yang menjadi pecandu narkotika, mabuk-mabukan, serta segala keterbatasan sarana yang dapat menstimulasi seseorang berkembang secara negative, (3) Lingkungan sekolah seperti Kondisi dan letak gedung sekolah buruk, misalnya dekat pasar, kndisi gurun atau alat-alat belajar yang berkualitas rendah. Lingkungan sekolah yang kurang mendukung saran belajar dapat mengacaukan konsentrasi belajar sebab berdampak pada penurunan kemampuan prestasi tinggi. Sangat jarang ditemukan siswa yang maju berasal dari lingkungan sekolah yang kurang kondusif. Oleh karena itu, suasana yang nyaman tanpa keributan, serta fasilitas belajar yang memadai, akan mendorong lahirnya siswa-siswi yang berprestasi tinggi.

Kesulitan ini dapat ditemui pada saat belajar dalam kelas yang sebagian peserta didik masih 
ada yang selalu tertinggal dalam mengerjakan tugas dengan waktu yang ditentukan dan hasil akhir rata-rata masih dibawah nilai KKM yang ingin dicapai. Beberapa peserta didik memiliki kemampuan yang masih agar rendah, sehingga dalam belajar fisika masih sangat kesulitan.Tujuan dilakukan penelitian ini adalah untuk mendeskripsikan kesulitan belajar fisika pada peserta didik dan Mendeskripsikan upayaupaya guru dalam mengatasi kesulitan belajar fisika pada peserta didik.

Secara umum bagi peneliti, penelitian ini bermanfaat sebagai syarat untuk mencapai gelar Program Sarjana Pendidikan Fisika. Dari hasil penelitian bagi peneliti bermanfaat dalam menambah wawasan tentang faktor-faktor kesulitan belajar fisika saat mengajar disekolah menengah atas (SMA). Penelitian ini juga dapat sebagai acuan dalam melaksanakan penelitian lebih lanjut terutama yang menggunakan populasi peserta didik Sekolah Menengah Atas, dan sebagai acuan dalam merumusakan solusi untuk upaya mengatasi kesulitan belajar pada peserta didik terkhusus pada mata pelajaran fiska.

\section{Metode Penelitian}

Penelitian ini merupakan penelitian kualitatif yang bersifat deskriptif, karena dalam penelitian ini berusaha menggambarkan suatu obyek tertentu yang dijadikan penelitian. Dimana penelitian kualitatif adalah suatu penelitian yang ditujukan untuk mendeskripsikan dan menganalisis fenomena, peristiwa, aktivitas sosial, sikap, kepercayaan, persepsi, pemikiran orang secara individual maupun kelompok. Dalam penelitian ini yang menjadi subjek penelitian adalah pada peseta didik kelas IPA yang mengalami kesulitan belajar.

Sumber data yang digunakan dalam penelitian ini adalah data primer yaitu data yang diperoleh langsung dari sumbernya, diamati dan dicatat untuk pertama kalinya ketika peneliti melakukan observasi di lokasi yang dijadikan objek penelitian yaitu peseta didik kelas IPA di SMAN Bontonompo dan data sekunder yaitu data yang bukan diusahakan sendiri pengumpulannya oleh peneliti misalnya dari biro statistik, majalah, keterangan-keterangan atau publikasi lainnya. Jadi kata skunder berasal dari tangan kedua, ketiga, dan seterusnya, artinya melewati satu atau lebih pihak yang bukan peneliti sendiri.

Tehnik pengumpulan data dilakukan dengan tiga metode yaitu metode observasi, dokumentasi dan wawancara. Observasi atau pengamtan sebagai alat penilaian banyak digunakan untuk mengukur tingkah laku individu atau pun proses terjadinya suatu kegiatan yang dapat diamati, baik dengan situasi yang sebenarnya maupun dalam situasi buatan. Metode Dokumentasi memiliki arti yang sangat penting dalam penelitian kulitatif. Karena secara jelas dokumentasi memberikan gambaran mengenai pengalaman hidup serta kejadian yang terdapat pada subyek dan obyek penelitian pada saat tertentu, dengan mencari dokumen atau data mengenai hal-hal atau variabel yang berupa catatan, buku, majalah serta agenda dan sebagainya. Metode interview/ wawancara adalah merupakan tanya jawab yang langsung untuk mendapatkan informasi. Ada tiga metode wawancara yang digunakan dalam penelitian ini yaitu wawancara terstruktur, semi terstruktur dan tidak terstruktur.

Data yang diperoleh dianalisis sebelum memasuki lapangan dilakukan terhadap data hasil studi pendahuluan, atau data sekunder, yang akan digunakan untuk menentukan fokus penelitian. Demikian fokus penelitian ini masih bersifat sementara, dan akan berkembang setelah peneliti masuk dan selama dilapangan. Analisis data dalam penelitian kualitatif, dilakukan pada saat pengumpulan data berlangsung, dan setelah pengumpulan data dalam periode tertentu. Pada saat wawancara, peneliti sudah melakukan analisis terhadap jawaban yang akan diwawancarai, bila jawaban yang diwawancarai setelah dianalisis terasa belum memuaskan, maka peneliti akan melanjutkan pertanyaan lagi, sampai tahab tertentu, diperoleh data yang dianggap kreadibel. Miles dan Huberman (1984), mengemukakan bahwa aktivitas dalam analisis data kualitatif dilakukan secara interaktif dan berlangsung secara terus-menerus sampai tuntas, hingga datanya sudah jenuh. Analisis data saat dilapangan meliputi (1) reduksi data, (2) penyajian data (display data), dan (3) penarikan kesimpulan (verivikasi)

\section{Hasil dan Pembahasan}


Ada beberapa temuan dalam penelitian ini diantaranya faktor internal yang mempengaruhi kesulitan belajar pesera didik yaitu: (1) pada saat pembelajaran fisika terutama pada siang hari, peserta didik ada yang cepat lelah, kurang bersemangat, mudah pusing, cepat mengantuk dikarenakan kondisi ruangan yang panas dan jumlah peserta didik yang cukup padat, (2) kemampuan daya tangkap dan keaktifan sebagian peserta didik berbeda-beda, ada yang aktif karena daya tangkapnya baik dan ada yang hanya diam atau melakukan hal-hal yang ia inginkan dan tidak memperhatikan pelajaran, (3) kurangnya minat peserta didik dalam belajar fisika yang menyebabkan mereka cepat mengantuk, mengeluh, asyik melakukan hal yang ia sukai dengan mengambar-gambar dibuku tulis, malas mencatat dan malas masuk kelas, (4) kemampuan sebagian dari peserta didik yang sangat kurang, terutama dalam penguasaan konsep, rumus dan perhitungan matematikanya yang masih sangat rendah, (5) kurangnya kesiapan peserta didik dalam belajar fisika seperti tidak membawa buku catatakan, tidak membawa pulpen dan tidak masuk kelas dengan alasan terlambat, (6) cara menyampaikan guru yang terkadang kurang jelas dibeberapa kelas karena suara ribut dari peserta didik yang berada dikelas dan kelas lain terutama yang peserta didik duduknya paling belakang, dan (7) aktif berorganisasi yang menyebabkan peserta didik tidak dapat mengatur waktu belajarnya.

Data tersebut dapat temukan pada saat penulis berada dalam kelas saat pembelajaran fisika berlangsung. Selain melakukan pengamatan, dari hasil wawancara dengan peserta didik dan pihak yang terkait, meneliti mendapatkan informasi bahwa peserta didik mengalami kesulitan belajar dikarenakan kebiasaan belajar yang tidak teratur disebabkan oleh tuntutan bekerja saat pulang sekolah dan kegiatan lain yang dapat membuat peserta didik tidak memiliki waktu belajar. Dari hasil data yang diperoleh maka kesimpulan bahwasanya peserta didik Sekolah Menengah Atas sangat dipengaruhi kesulitan belajarnya dari segi faktor dari dalam dirinya sendiri (internal). Kesulitan belajar yang penulis temukan pada peserta didik tak lepas dari teori yang ada sebelumya, yang menjadi panduan untuk memperoleh data yang lebih akurat.
Sementara itu untuk faktor ekternal kesulitan belajar fisika pada peserta didik meliputi: (1) Suasana belajar yang tidak kondusif terutama disiang hari yang cuacanya panas dan ada beberapa kelas yang jumlah peserta didiknya cukup padat, (2) Gangguan belajar pada peserta didik saat belajar kerena kehadiran seseorang yang ribut dan lewat-lewat didepan kelasnya yang dapat mengundang perhatian peserta didik, (3) Suara bising yang membuat peserta didik terganggu dalam belajarnya yang berasaal dari kelas sendiri atau dari kelas yang berseblahan karena bunyi kursi yang bergesekan dilantai, (4) Gangguan dari jenis kelamin terutama yang sedang bermasalah dengan teman dan pacarnya sehingga lupa untuk belajar, (5) Tidak adanya teman belalajar karena faktor ketidak cocokan pendapat dan sifat suka menyendiri, (6) Teman sepermainan yang nakal sehingga ikut terpengaruh kedalamnya yang menyebabkan peserta didik malas belajar, dan (7) Tidak dapat mengatur waktu belajar disebabkan malas belajar, aktif organisasi dan sibuk bekerja membantu orang tua.

Pada dasarnya baik faktor internal dan ekternal kesulitan belajar peserta didik mata pelajaran fisika sesuai dengan teori yang ada sebelumnya. Perbedaan pada hasil penulisan dengan teori terletak pada faktor penyebab kesulitan belajar itu sendiri. Dari hasil pengamatan yang dilakukan, data faktor kesulitan belajar dan yang mempengaruhi belajar hampir sama penyebabnya. Faktor-faktor kesulitan belajar baik faktor internal dan ekternal saling mempengaruhi satu sama lain. Hal ini dipengaruhi oleh berbagai aspek baik yang internal maupun yang eksternal. Setiap aspek yang diteliti baik faktor internal dan ekternal pada dasarnya saling berkaitan dan tak dapat dipisahkan dan berjalan secara bersamaan pada peserta didik. Adanya faktor internal karena pengaruh faktor ekternal dan begitu pula dengan sebailknya. Faktor-faktor kesulitan belajar, tinggal selanjutnya menjadi tantangan para guru fisika Sekolah Menengah Atas dalam berupaya mengatasi kesulitan belajar peserta didik mata pelajarn fisika.

\section{Kesimpulan}

Dalam membuat kesimpulan ini, peneliti mengacu pada semua data yang dikumpulkan yang telah dianalisis sesuai dengan rumusan masalah dan 
tujuan penelitian yang telah dirumuskan. Berdasarkan pendekatan kualitatif dengan jenis penelitian deskriptif dalam menganalisis faktorfaktor kesulitan belajar mata pelajaran fisika maka diperoleh faktor-faktor kesulitan belajar peserta didik pada mata pelajaran fisika pada dasarnya dipengaruhi oleh faktor internal dan faktor ekternal. Faktor internal meliputi kurangnya kemampuan peserta didik dalam matematika sebagai bahasa fisika, kesehatan yang sering terganggu, kurangnya minat belajar, kurangnya perhatian dalam pembelajaran, malas belajar dan kebiasaan belajar yang tidak teratur. Faktor ekternal meliputi pembelajaran yang diselenggarakan dimana peserta didik dalam jumlah besar (padat), kurangnya tontrol orang tua, tuntutan pekerjaan, aktif berorganisasi, teman sepermainan yang nakal dan pergaulan bebas.

\section{Daftar pustaka}

A. Wawan dan Dewi M. 2010. teori dan pengukuran pengetahuan,sikap, dan perilaku manusia, Yogyakarta: Nuha Medika.

Hasbullah, 2005, Dasar-dasar ilmu pendidikan. Jakarta: PT Raja Graha findo Persada.

Haidar Putra Daulay, 2009, Pembelajaran pendidikan islam di Indonesia, Jakarta: PT Rineka Cipta.

Trianto, 1989, Model Pembelajaran Terpadu Konsep, Strategi, dan Implementasinya dalam Kurikulum Tingkat Satuan Pendidikan (KTSP), Jakarta: PT. Bumi Aksara.

Hugh D. Young and Roger A. Freedman, 2001, Fisika Universitas Edisi Sepuluh. Bandung: Erlangga.

Drs. Sumadin Suryabrata, 2004, Psikologi pendidikan, Jakarta: PT Raja Grafindo Persada.

Ulfiani Rahman, 2014, Memahami psikologi dalam pendidikn, teori dan aplikasi, Makassar:UIN Press.

Nana Syaodih Sukmadinata, 2010, Metode Penelitian Pendidikan, Bandung: PT. Remaja Rosdakarya.
Marzuki, 2000, Metodologi Riset. Yogyakarta PT Prasetia Widia Pratama.

Drs. Beni Ahmad Saebani, M.Si, 2007, Metode penelitian, Bandung; UIN Sunan Gunung Jati.

Husaini Usman, 2009 , Metodologi Penelitian Sosial, Cet. 2:Jakarta: PT. Bumi Aksara.

Suharsimi Arikunto. 2006, Proposal penelitian suatu pendekatan praktek, Jakarta: Rineka Cipta.

Dr Sugiono, 2014, Metode penelitian pendidikan, pendekatan kuantitatif, kualitatif dan $R$ dan D, Bandung: Alfabeta. 